\title{
Anxiolytic activity of aerial part hydroethanolic extract of Allium ascalonicum Linn. (Liliaceae) in mice
}

\author{
Abidemi J. Akindele*, Hakeem A. Sanni, and Pamela C. Edeh \\ Department of Pharmacology, Faculty of Basic Medical Sciences, College of Medicine, \\ University of Lagos, P.M.B. 12003 Lagos, Nigeria \\ *Corresponding Author: Abidemi J. Akindele (PhD), Department of Pharmacology, Faculty of \\ Basic Medical Sciences, College of Medicine, University of Lagos, P.M.B. 12003 Lagos, \\ Nigeria
}

Submission date: July 30, 2012, Acceptance date: November 6, 2012; Publication date: November 19, 2012

Running Title: Anxiolytic activity of Allium ascalonicum

\begin{abstract}
Background: Allium ascalonicum Linn. (Liliaceae) is a mildly aromatic annual herb used to flavor food. Ethnobotanical survey revealed application of A. ascalonicum in the treatment of central nervous system (CNS) disorders.
\end{abstract}

Objective: To investigate the anxiolytic activity of aerial part hydroethanolic extract of $A$. ascalonicum.

Methods: The hole-board, elevated plus maze, light/dark exploration, open field and social interaction tests were used in this study. Groups of mice were treated orally with distilled water $(10 \mathrm{ml} / \mathrm{kg})$, diazepam $(1 \mathrm{mg} / \mathrm{kg})$, and A. ascalonicum $(50-400 \mathrm{mg} / \mathrm{kg})$. Evaluations were done $1 \mathrm{~h}$ post-treatment and the duration of observation was mostly $5 \mathrm{~min}$. In the hole-board test, mice were observed for number/duration of head dips and number of sectional crossings. In the elevated plus maze test, the time spent in the open/closed arms and the number of entries by mice were observed. In the light/dark exploration test, the latency of entry into the dark box, time spent in the light and dark compartments, number of rearing and assisted rearing were determined. In respect of the open field test, observations were made for the number of rearing, assisted rearing, and sectional crossings. In the social interaction test, pairs of mice were observed for number of interactions including sniffing, following, and partner grooming.

Results: In the hole-board test, $A$. ascalonicum significantly $(\mathrm{p}<0.05,0.01)$ increased the number/duration of head dips and number of sectional crossings. In the elevated plus maze test, A. ascalonicum significantly $(\mathrm{p}<0.05)$ increased the number of entries into the open arm with 
corresponding reduction in number of entries into the closed arm. In the light/dark exploration test, $A$. ascalonicum significantly ( $\mathrm{p}<0.05,0.01)$ increased the latency of entry into the dark box, time spent in the light box, and number of rearing and assisted rearing. In respect of the open field test, A. ascalonicum significantly $(\mathrm{p}<0.05,0.01)$ increased the number of sectional crossings and rearing. Considering the social interaction test, A. ascalonicum significantly $(p<0.05)$ increased the number of interactions. Peak anti-anxiety effects were mostly observed at the dose of $100 \mathrm{mg} / \mathrm{kg}$.

Conclusion: The aerial part hydroethanolic extract of Allium ascalonicum possesses anxiolytic properties.

Keywords: Allium ascalonicum, Liliaceae, anxiolytic activity, medicinal plants, traditional medicine.

\section{INTRODUCTION:}

Medicinal plants have continued to be relevant in the treatment of diverse disease conditions across the world in developing and developed countries. Wambebe [1] and Gilani and Atta-urRahman [2] respectively reported that $70 \%$ of indigenous populations in developing countries rely on phytotherapy and $25 \%$ of drugs in typical western pharmacies are plant-derived. The official recognition of traditional medical practices, including the application of botanicals, and successful integration into the national healthcare delivery system in countries like China and Indian is indicative of the therapeutic values of herbal remedies. The reliability of history of use in ethnomedicine is significant to the extent that it is a prominent rationale for the selection of plants for scientific scrutiny towards the discovery of new drugs and lead compounds. The motivation for the search for new drugs from plants is to discover medicines with enhanced efficacy and safety profile compared to presently available drugs.

Health problems warranting the use of drugs which impact on the central nervous system, including anxiolytics, sedatives, antidepressants, antipsychotics et al., are a common and costly problem worldwide and traditional African healers treat mental illnesses and disorders of the CNS using a variety of indigenous plants [3,4]. The perceived advantages ascribed to effective botanicals include relative safety, availability, and cheaper cost.

Allium ascalonicum Linn.(Liliaceae), commonly called shallot and spring onion, is an annual herbaceous plant widely found in Nigeria. The plant, widely used to flavor food, is locally known in the country as Alubosa-elewe, Albasa and Maigo. Ethnobotanical survey conducted among traditional medicine practitioners, who engage in herbalism, in Mushin area of Lagos State, Nigeria, revealed wide application of A. ascalonicum in the treatment of CNS related disorders. This study was designed to investigate the anxiolytic activity of aerial part hydroethanolic extract of A. ascalonicum in mice.

\section{MATERIALS AND METHODS:}

This study, conducted to investigate the anxiolytic activity of the aerial part hydroethanolic 
extract of A. ascalonicum in Swiss mice, lasted for 6 months and commenced with the procurement of the plant material and extraction in the month of April 2011. Acute toxicity test and phytochemical analysis were initially carried out followed by the evaluation of anxiolytic activity using hole-board, elevated plus maze, open-field, light/dark exploration and social interaction tests in acclimatized experimental animals.

Plant material and extraction: A. ascalonicum aerial parts were obtained from a traditional herb dealer in Mushin, Lagos State, Nigeria. The plant was identified and authenticated by Prof. J.D. Olowokudejo and Mr. T.K. Odewo of the Department of Botany, University of Lagos, Nigeria. A voucher specimen, numbered LUH3559, was deposited at the herbarium of the Department.

Fresh aerial parts of $A$. ascalonicum were rinsed in water, cut into small pieces, and pounded into fine slurry with mortar and pestle. One hundred $\mathrm{g}$ of the material was macerated for $48 \mathrm{~h}$ in $1 \mathrm{~L}$ hydroethanol (1:1) and exhaustive extraction was achieved by macerating the derived residue again in hydroethanol for $48 \mathrm{~h}(\times 2)$. The filtrates obtained from each maceration process were combined and evaporated to dryness at $40^{\circ} \mathrm{C}$ under reduced pressure. A dark brown solid extract with a yield of $40 \%$ was obtained. The dried extract was reconstituted in distilled water before each experimental session.

Experimental animals: Swiss mice (15-30 g) of both sexes used in this study were obtained from the Laboratory Animal Center of College of Medicine, University of Lagos, Lagos, Nigeria. The animals were kept in well-ventilated hygienic compartments maintained under standard environmental conditions $\left(23-25^{\circ} \mathrm{C}, 12 \mathrm{~h} / 12 \mathrm{~h}\right.$ light/dark cycle) and were fed with standard rodent diet (Livestock Feed PLC, Lagos, Nigeria) and water ad libitum. Mice were acclimatized for 14 days before the commencement of the experiment. The protocol adopted in this study was in accordance with the provisions of the Experimentation Ethics Committee on Animal Use of the College of Medicine, University of Lagos, Lagos, Nigeria and the United States National Academy of Sciences Guide for the Care and Use of Laboratory Animals [5].

\section{Acute toxicity test:}

Animals used in this study were fasted for $12 \mathrm{~h}$ prior to the commencement of the experiment. The aerial part hydroethanolic extract of A. ascalonicum was administered orally (p.o.) up to 10 $\mathrm{g} / \mathrm{kg}$ to groups of mice. The extract was also administered to 4 groups of 5 mice each intraperitoneally (i.p.) at doses of 1000, 2000, 3000, and $5000 \mathrm{mg} / \mathrm{kg}$. Separate groups of mice which served as control received distilled water at the highest volume of the extract administered for p.o. and i.p. routes. In all cases, animals were observed for $2 \mathrm{~h}$ post-treatment for behavioral changes and signs of toxicity. Mortality was recorded $24 \mathrm{~h}$ later and surviving mice were observed for a further 14 days for signs of delayed toxicity. The LD50 was estimated by the log dose-probit analysis method of Miller and Tainter [6].

Phytochemical analysis: Phytochemical screening was carried out on A. ascalonicum extract using the methods of Trease and Evans [7] to determine the presence of various major classes of 
phytoconstituents.

\section{Anxiolytic activity tests:}

Hole-board test: The hole-board is a white painted wooden board $(40 \mathrm{~cm} \times 40 \mathrm{~cm}$ ) with four equidistant holes $(1 \mathrm{~cm}$ diameter $\times 2 \mathrm{~cm}$ depth). Using two thick colored lines which intersect at the centre, the board was divided into 4 equal sectional squares of $20 \mathrm{~cm} \times 20 \mathrm{~cm}$ [4]. One hour after oral treatment of 6 groups of 5 mice each with distilled water $(10 \mathrm{ml} / \mathrm{kg})$, A. ascalonicum $(50,100,200$ and $400 \mathrm{mg} / \mathrm{kg})$ and diazepam $(1 \mathrm{mg} / \mathrm{kg})$, each mouse was placed in turn ane corner of the board with the animal subsequently moving about and dipping its head into the holes. The number and duration of head dips, and number of sectional crossings in 5 min. were recorded for individual mouse [8].

Elevated plus maze test: The plus maze consists of two open arms and two closed arms $(50 \times$ $10 \times 40 \mathrm{~cm}$ each) elevated to a height of $50 \mathrm{~cm} \mathrm{[9].} \mathrm{Distilled} \mathrm{water}(10 \mathrm{ml} / \mathrm{kg}, \mathrm{p} . \mathrm{o}), A$. ascalonicum (50, 100, 200 and $400 \mathrm{mg} / \mathrm{kg}$, p.o) and diazepam (1 mg/kg, p.o) were administered to 6 groups of 5 mice each. One hour post-treatment, each mouse was placed in turn in the centre of the maze facing one of the closed arms. The cumulative times spent by each mouse in the open and closed arms of the maze and the number of entries was recorded for $5 \mathrm{~min}$.

Open-field test: Thirty mice allotted into 6 groups of 5 animals each were used in this study. The apparatus was made of wood $50 \mathrm{~cm}$ in length, $50 \mathrm{~cm}$ in width, and $25 \mathrm{~cm}$ in height. The plain floor of the box was divided into $8 \mathrm{~cm}$ by $8 \mathrm{~cm}$, with 16 squares on it. Sixteen squares were defined as the center and the others adjacent to the walls as the periphery. A $60 \mathrm{~W}$ white bulb illuminated the apparatus. One hour after oral administration with vehicle (distilled water 10 $\mathrm{ml} / \mathrm{kg}$ ), standard (diazepam $1 \mathrm{mg} / \mathrm{kg}$ ), and extract (50, 100, 200, and $400 \mathrm{mg} / \mathrm{kg}$ ), each mouse was gently placed at the center of the open field and number of squares crossed was counted for $5 \mathrm{~min}$. The mouse was taken out of the apparatus after $5 \mathrm{~min}$. and the floor was cleaned with ethanol. A mouse was deemed to have crossed over from one square to another when all four paws had crossed. The number of rearings and assisted rearings (when the fore paws are placed on a wall of the open field) within the observation period of $5 \mathrm{~min}$. was recorded $[8,10]$.

Light/dark exploration test: Natural aversion of rodents from brightly lit places was evaluated in the light/dark transition model. The light/dark box is a rectangular box of $50 \times 25 \times 25 \mathrm{~cm}$, which is divided into 2 compartments (light and dark). For this experiment, albino mice were divided into six groups, each group comprising of five animals. Vehicle (distilled water 10 $\mathrm{ml} / \mathrm{kg}$ ), standard (diazepam $1 \mathrm{mg} / \mathrm{kg}$ ), and extract $(50,100,200$, and $400 \mathrm{mg} / \mathrm{kg}$ ) were administered p.o. One hour after administration, each mouse was placed individually in the illuminated part of the light/dark box. During the test session of $5 \mathrm{~min}$., latency (the time it takes for the animal to move into the dark compartment for the first time), number of entries into the light and dark compartments, total time spent in the light compartment, and visible number of rearings and assisted rearings were recorded $[8,11]$. 
Social interaction test: In this test, the amount of time a pair of mice spend socially interacting with one another reflects the level of anxiety. The duration of social interaction decreases with increased anxiety. Mice were placed individually in the test arena for $7 \mathrm{~min}$. familiarization session on two consecutive days. On the test day, groupings and treatments were done: distilled water (10 ml/kg; Group 1), diazepam (1 mg/kg; Group 2), and A. ascalonicum (50, 100, 200, and $400 \mathrm{mg} / \mathrm{kg}$; Groups 3, 4, 5, and 6). Two randomly selected mice from the same group were placed in adjacent cages in the waiting area of the test room. One hour post-treatment, each pair of mice were in turn introduced together into the center of the test arena. Social interaction was observed remotely for $7 \mathrm{~min}$. The number of occurrences of social interactions (sniffing, following, and grooming the partner) were recorded [12].

Statistical analysis: Results obtained in this study were expressed as mean \pm S.E.M. $(n=5)$. The data were analyzed using One-way ANOVA (followed by Tukey's post-hoc test) and Student's $t$-test (unpaired, two-tailed) using GraphPad Prism 5 Software (GraphPad Software Inc., CA, USA). Results were considered significant when $P<0.05$.

\section{RESULTS:}

Acute toxicity test: A. ascalonicum did not produce any mortality administered orally up to 10 $\mathrm{g} / \mathrm{kg}$, but mice manifested signs of sedation like quiescence and reduced locomotion at the higher doses of 5-10 g/kg when observed for $2 \mathrm{~h}$ post-treatment. No visible signs of delayed toxicity and mortality were observed when the animals were monitored for a further 14 days. In respect of the i.p. route, mortality was 20 and $100 \%$ respectively at the lowest dose of 1000 and highest dose of $5000 \mathrm{mg} / \mathrm{kg}$. At the higher doses of 3000 and $5000 \mathrm{mg} / \mathrm{kg}$, animals showed signs of sedation and writhing. The $\mathrm{LD}_{50}$ administered i.p. was estimated to be $2238.72 \mathrm{mg} / \mathrm{kg}$.

Phytochemical analysis: Preliminary screening of $A$. ascalonicum extract revealed the presence of alkaloids, tannins, glycosides, anthraquinones, phlobatannins, and flavonoids.

\section{Anxiolytic activity tests:}

Hole-board test: A. ascalonicum significantly ( $\mathrm{p}<0.05,0.01)$ and dose-dependently increased the number of head dips with values being $2.00 \pm 0.32,3.80 \pm 0.80,4.40 \pm 0.87$ and $5.80 \pm 0.86$ respectively at doses of $50,100,200$, and $400 \mathrm{mg} / \mathrm{kg}$, compared to a value of $1.20 \pm 0.37$ for control. Peak effect was produced at the dose of $400 \mathrm{mg} / \mathrm{kg}$. Diazepam slightly increased the number of head dips but this effect was not significant. The value for the extract at $400 \mathrm{mg} / \mathrm{kg}$ was significantly $(\mathrm{p}<0.01)$ higher than that of diazepam $(5.80 \pm 0.86$ vs. $1.60 \pm 0.24)$. In respect of duration of head dips, A. ascalonicum significantly $(\mathrm{p}<0.01,0.001)$ increased the duration of head dips giving values of $32.50 \pm 4.37,36.50 \pm 7.19,30.00 \pm 7.02$, and $16.00 \pm 5.82$ seconds relative to $3.00 \pm 1.23$ seconds for control. Peak effect was produced at the dose of $100 \mathrm{mg} / \mathrm{kg}$. Diazepam increased the duration of head dips but this effect was also not significant. The effect of the extract at the dose of $100 \mathrm{mg} / \mathrm{kg}$ was higher than that of diazepam. For the number of sectional crossings, there was no significant difference between the effect of diazepam (5.20 \pm $1.59)$ and control $(3.80 \pm 1.46)$. A. ascalonicum significantly $(\mathrm{p}<0.001)$ increased the number of 
sectional crossings at doses of 100, 200, and $400 \mathrm{mg} / \mathrm{kg}$ with peak effect produced at dose of 200 $\mathrm{mg} / \mathrm{kg}$. This effect was significantly $(\mathrm{p}<0.01)$ higher than that of diazepam (Table 1$)$.

Table 1: Effect of A. ascalonicum aerial part hydroethanolic extract in Hole board test

\begin{tabular}{ccccc}
\hline Treatment & Dose & No of head dips & $\begin{array}{c}\text { Duration of } \\
\text { head dips } \\
\text { (seconds })\end{array}$ & $\begin{array}{c}\text { No. of sectional } \\
\text { crossings }\end{array}$ \\
\hline Distilled water & $(10 \mathrm{ml} / \mathrm{kg})$ & $1.20 \pm 0.37$ & $3.00 \pm 1.23$ & $3.80 \pm 1.46$ \\
\hline Diazepam & 1 & $1.60 \pm 0.24$ & $14.75 \pm 6.25$ & $5.20 \pm 1.59$ \\
\hline A. ascalonicum & 50 & $2.00 \pm 0.32$ & $32.50 \pm 4.37^{\mathrm{c}}$ & $5.20 \pm 1.63$ \\
\hline A. ascalonicum & 100 & $3.80 \pm 0.80^{\mathrm{a}}$ & $36.50 \pm 7.19^{\mathrm{b}}$ & $15.40 \pm 1.25^{\mathrm{c}}$ \\
\hline A. ascalonicum & 200 & $4.40 \pm 0.87^{\mathrm{b}}$ & $30.00 \pm 7.02^{\mathrm{b}}$ & $19.00 \pm 2.32^{\mathrm{c}, \beta}$ \\
\hline A. ascalonicum & 400 & $5.80 \pm 0.86^{\mathrm{b}, \beta}$ & $16.00 \pm 5.82$ & $16.60 \pm 1.44^{\mathrm{c}}$ \\
\hline
\end{tabular}

Values are mean \pm S.E.M $(n=5) .{ }^{a} p<0.05,{ }^{b} p<0.01,{ }^{c} p<0.001$ vs. Distilled water; ${ }^{\beta} p<0.01$ vs. Diazepam.

Elevated plus maze test: As shown in Table 2, A. ascalonicum produced a non-significant increase in the time spent in the open arms with peak effect produced at the dose of $100 \mathrm{mg} / \mathrm{kg}$ (276.5 \pm 4.74 seconds) relative to control (180.0 \pm 51.30 seconds). In respect of entry into open arms, the extract at the dose of $100 \mathrm{mg} / \mathrm{kg}$ significantly $(\mathrm{p}<0.05)$ increased the number of entries $(8.20 \pm 0.73)$ compared to control $(4.60 \pm 1.33)$. The number of entries into the closed arms was significantly $(\mathrm{p}<0.05)$ reduced by $A$. ascalonicum at doses of 50 and $400 \mathrm{mg} / \mathrm{kg}$, and diazepam, with values of $4.20 \pm 1.50,3.20 \pm 1.74$, and $3.40 \pm 1.50$ respectively, compared to control $(8.20 \pm$ 0.86). The effect produced by the extract at the dose of $400 \mathrm{mg} / \mathrm{kg}$ was comparable to that of diazepam.

Table 2: Effect of A. ascalonicum aerial part hydroethanolic extract in Elevated plus maze test

\begin{tabular}{ccccc}
\hline Treatment & $\begin{array}{c}\text { Dose } \\
(\mathbf{m g} / \mathbf{k g})\end{array}$ & $\begin{array}{c}\text { Time spent in } \\
\text { open arms } \\
\text { (seconds) }\end{array}$ & $\begin{array}{c}\text { No. of entries } \\
\text { into open arms }\end{array}$ & $\begin{array}{c}\text { No. of entries } \\
\text { into closed } \\
\text { arms }\end{array}$ \\
\hline Distilled water & $(10 \mathrm{ml} / \mathrm{kg})$ & $180.00 \pm 51.30$ & $4.60 \pm 1.33$ & $8.20 \pm 0.86$ \\
\hline Diazepam & 1 & $206.50 \pm 30.29$ & $6.20 \pm 1.66$ & $3.40 \pm 1.50^{\mathrm{a}}$ \\
\hline A. ascalonicum & 50 & $255.30 \pm 8.12$ & $5.80 \pm 0.92$ & $4.20 \pm 1.50^{\mathrm{a}}$ \\
\hline A. ascalonicum & 100 & $276.50 \pm 4.74$ & $8.20 \pm 0.73^{\mathrm{a}}$ & $7.00 \pm 0.71$ \\
\hline A. ascalonicum & 200 & $231.50 \pm 10.05$ & $7.40 \pm 0.93$ & $8.40 \pm 1.57$ \\
\hline A. ascalonicum & 400 & $198.50 \pm 45.68$ & $4.80 \pm 1.11$ & $3.20 \pm 1.74^{\mathrm{a}}$ \\
\hline
\end{tabular}

Values are mean \pm S.E.M. $(n=5) .{ }^{a} p<0.05$ vs. Distilled water.

Open-field test: As shown in Table 3, diazepam $(\mathrm{p}<0.05)$ produced a slight non-significant increase in the number of rearing compared to control $(9.60 \pm 1.75$ vs. $7.60 \pm 2.25)$. At the dose of $100 \mathrm{mg} / \mathrm{kg}$, A. ascalonicum produced a significant $(\mathrm{p}<0.05)$ increase in the number of rearing 
giving a value of $15.60 \pm 1.69$ relative to control. This effect was significantly $(\mathrm{p}<0.05)$ higher than that of diazepam. In respect of assisted rearing, diazepam also non-significantly increased the number of assisted rearing compared to control $(17.20 \pm 2.75$ vs. $11.60 \pm 3.76)$. A. ascalonicum at the dose of $100 \mathrm{mg} / \mathrm{kg}$ increased the number of assisted rearing (20.00 \pm 1.09$)$ but this effect was not significant. For the number of sectional crossings, A. ascalonicum significantly $(\mathrm{p}<0.05,0.01)$ increased the number of sectional crossings with peak effect produced at the dose $100 \mathrm{mg} / \mathrm{kg}$ with a value of $71.40 \pm 3.23$ compared to $49.40 \pm 4.23$ for control. Diazepam also significantly $(\mathrm{p}<0.01)$ increased the number of sectional crossings $(69.80$ \pm 3.43 ) relative to control. The effects of $A$. ascalonicum at $100 \mathrm{mg} / \mathrm{kg}$ and diazepam were comparable and not significantly different ( $p>0.05)$. There was no significant difference between the effects of the extract at the various doses.

Table 3: Effect of A. ascalonicum aerial part hydroethanolic extract in the Open field test

\begin{tabular}{ccccc}
\hline Treatment & Dose $(\mathbf{m g} / \mathbf{k g})$ & No. of rearing & $\begin{array}{c}\text { No. of assisted } \\
\text { rearing }\end{array}$ & $\begin{array}{c}\text { No. of sectional } \\
\text { crossings }\end{array}$ \\
\hline Distilled water & $(10 \mathrm{ml} / \mathrm{kg})$ & $7.60 \pm 2.25$ & $11.60 \pm 3.76$ & $49.40 \pm 4.23$ \\
\hline Diazepam & 1 & $9.60 \pm 1.75$ & $17.20 \pm 2.75$ & $69.80 \pm 3.43^{\mathrm{b}}$ \\
\hline A. ascalonicum & 50 & $7.20 \pm 3.79$ & $14.00 \pm 1.70$ & $68.40 \pm 5.64^{\mathrm{a}}$ \\
\hline A. ascalonicum & 100 & $15.60 \pm 1.69^{\mathrm{a}, \mathrm{a}}$ & $20.00 \pm 1.09$ & $71.40 \pm 3.23^{\mathrm{b}}$ \\
\hline A. ascalonicum & 200 & $4.20 \pm 1.93$ & $12.20 \pm 0.97$ & $52.80 \pm 3.89$ \\
\hline A. ascalonicum & 400 & $9.60 \pm 1.97$ & $16.60 \pm 2.18$ & $68.20 \pm 5.17^{\mathrm{a}}$ \\
\hline
\end{tabular}

Values are mean \pm S.E.M. $(n=5) .{ }^{a} \mathrm{p}<0.05,{ }^{b} \mathrm{p}<0.01$ vs. Distilled water; ${ }^{\alpha} \mathrm{p}<0.05$ vs. Diazepam.

\section{Light/dark exploration test:}

As shown in Table 4, A. ascalonicum at doses of $50-200 \mathrm{mg} / \mathrm{kg}$ significantly $(\mathrm{p}<0.05,0.01)$ increased the latency of entry into the dark box with peak effect produced at the dose of 100 $\mathrm{mg} / \mathrm{kg}(5.60 \pm 0.51$ seconds $)$ compared to control $(1.80 \pm 0.66$ seconds $)$. The extract at doses of $100-400 \mathrm{mg} / \mathrm{kg}$ significantly $(\mathrm{p}<0.05,0.01)$ increased the time spent in the light box with peak effect at the dose of $100 \mathrm{mg} / \mathrm{kg}(136.0 \pm 21.45$ seconds $)$ compared to control $(34.00 \pm 5.63$ seconds). The effect at this dose was not significantly different from that of diazepam (84.00 \pm 16.29 seconds). In respect of rearing, A. ascalonicum at doses of $100-400 \mathrm{mg} / \mathrm{kg}$ significantly $(\mathrm{p}<0.05,0.01)$ increased the number of rearing with peak effect at the dose of $100 \mathrm{mg} / \mathrm{kg}(4.80 \pm$ 1.32) relative to control $(0.40 \pm 0.40)$. Considering assisted rearing, the extract at doses of 50 $400 \mathrm{mg} / \mathrm{kg}$ also significantly $(\mathrm{p}<0.05,0.01)$ increased the number of assisted rearing but peak effect was at the dose of $400 \mathrm{mg} / \mathrm{kg}(11.00 \pm 1.92)$ compared to control (1.60 \pm 0.93$)$. In respect of latency of entry into the dark box and number of rearing, the values for A. ascalonicum at the dose of $100 \mathrm{mg} / \mathrm{kg}$ were significantly $(\mathrm{p}<0.05,0.001)$ higher than the values for diazepam. 
Table 4: Effect of A. ascalonicum aerial part hydroethanolic extract in the Light/dark exploration test

\begin{tabular}{lllllll}
\hline \multicolumn{1}{|c}{ Treatment } & $\begin{array}{l}\text { Dose } \\
(\mathbf{m g} / \mathbf{k} \\
\text { g) }\end{array}$ & $\begin{array}{l}\text { Latency of } \\
\text { entry into } \\
\text { the dark } \\
\text { box(seconds) }\end{array}$ & $\begin{array}{l}\text { Time in } \\
\text { light box } \\
\text { (seconds) }\end{array}$ & $\begin{array}{l}\text { Time in dark } \\
\text { box (seconds) }\end{array}$ & $\begin{array}{l}\text { No. of } \\
\text { rearing }\end{array}$ & $\begin{array}{l}\text { No. of } \\
\text { assisted } \\
\text { rearing }\end{array}$ \\
\hline Distilled water & $\begin{array}{l}(10 \\
\mathrm{ml} / \mathrm{kg})\end{array}$ & $1.80 \pm 0.66$ & $34.00 \pm 5.63$ & $218.00 \pm 23.59$ & $0.40 \pm 0.40$ & $1.60 \pm 0.93$ \\
\hline Diazepam & 1 & $1.80 \pm 0.20$ & $84.00 \pm 16.29^{\mathrm{a}}$ & $119.00 \pm 9.12^{\mathrm{b}}$ & $0.80 \pm 0.37$ & $7.60 \pm 1.21^{\mathrm{b}}$ \\
\hline A. ascalonicum & 50 & $4.80 \pm 0.66^{\mathrm{a}}$ & $56.40 \pm 9.24$ & $192.00 \pm 18.94$ & $0.80 \pm 0.58$ & $6.80 \pm 0.80^{\mathrm{b}}$ \\
\hline A. ascalonicum & 100 & $5.60 \pm 0.51^{\mathrm{b}, \gamma}$ & $136.00 \pm 21.45^{\mathrm{b}}$ & $163.20 \pm 27.60$ & $4.80 \pm 1.32^{\mathrm{a}, \alpha}$ & $10.60 \pm 1.78^{\mathrm{b}}$ \\
\hline A. ascalonicum & 200 & $3.80 \pm 0.37^{\mathrm{a}}$ & $68.40 \pm 13.55^{\mathrm{a}}$ & $117.40 \pm 20.44$ & $4.40 \pm 0.98^{\mathrm{b}}$ & $9.60 \pm 2.46^{\mathrm{a}}$ \\
& & & & & & \\
\hline A. ascalonicum & 400 & $2.80 \pm 0.20$ & $108.00 \pm 15.23^{\mathrm{b}}$ & $159.00 \pm 10.55^{\mathrm{a}}$ & $3.20 \pm 0.49^{\mathrm{b}}$ & $11.00 \pm 1.92^{\mathrm{b}}$ \\
& & & & & & \\
\hline
\end{tabular}

Values are mean \pm S.E.M. $(n=5) .{ }^{a} \mathrm{p}<0.05,{ }^{b} \mathrm{p}<0.01$ vs. Distilled water; ${ }^{a} \mathrm{p}<0.05,{ }^{\gamma} \mathrm{p}<0.001$ vs. Diazepam.

Social interaction test: The number of social interactions in the control group was $13.67 \pm 2.91$. A. ascalonicum increased the number of social interactions with peak significant effect $(\mathrm{p}<0.01)$ observed at the dose of $100 \mathrm{mg} / \mathrm{kg}(28.33 \pm 4.41)$. The value for diazepam $(11.80 \pm 0.80)$ was not significant $(\mathrm{p}>0.05)$ relative to the control (Table 5).

Table 5: Effect of A. ascalonicum aerial part hydroethanolic extract in the Social interaction test

\begin{tabular}{ccc}
\hline Treatment & $\begin{array}{c}\text { Dose } \\
(\mathbf{m g} / \mathbf{k g})\end{array}$ & $\begin{array}{c}\text { Number of } \\
\text { social interactions }\end{array}$ \\
\hline Distilled water & $(10 \mathrm{ml} / \mathrm{kg})$ & $13.67 \pm 2.91$ \\
\hline Diazepam & 1 & $11.80 \pm 0.80$ \\
\hline A. ascalonicum & 50 & $19.33 \pm 1.86$ \\
\hline A. ascalonicum & 100 & $28.33 \pm 4.41^{\mathrm{b}}$ \\
\hline A. ascalonicum & 200 & $27.67 \pm 7.22$ \\
\hline A. ascalonicum & 400 & $26.67 \pm 4.41$ \\
\hline
\end{tabular}

Values are mean \pm S.E.M $(n=5$ pair $) .{ }^{a} p<0.05,{ }^{b} p<0.01$ vs. Distilled water.

\section{DISCUSSION:}

Over the years, different pharmacological models have been employed in the evaluation of medicinal plants for neuropharmacological activities towards the identification of botanicals and drugs with beneficial effects in the treatment of diverse CNS disorders. The choice of test methods not only determines effectiveness but in some instances also gives an indication of the mechanism(s) of the test substance. In this study, the hole-board, elevated plus maze, light/dark 
exploration, open field and social interaction tests were used to investigate the anxiolytic effect of the aerial part hydroethanolic extract of A. ascalonicum in mice. The plant is a mildly aromatic herb used like onions to flavor food, including meats and sauces [13]. Adeniyi and Anyiam [14] reported that the bulb of shallot is of considerable importance in African cooking and in salads.

The hole-board model indicates that head-dipping behaviour is sensitive to changes in the emotional state of the animal and suggests that the expression of an anxiolytic state in animals may be reflected by an increase in head-dipping behaviour [8, 15]. In this study, A. ascalonicum significantly increased the number and duration of head dips with peak effects produced at doses of 400 and $100 \mathrm{mg} / \mathrm{kg}$ respectively, suggesting anxiolytic effect. At these doses, the extract also significantly increased the number of sectional crossings indicating that the anxiolytic effect of A. ascalonicum is associated with increase in locomotion.

The elevated plus maze is a standard pharmacological model for evaluating the anxiolytic effect of drugs and it is based on the fact that exposure of animals to an elevated plus maze evoke approach-avoidance conflict stronger than elicited by the exposure to an enclosed arm [8, 16]. Anxiolytic effect is indicated by decrease in aversion to the open arms by way of increase in time spent and entries into the open arms [8], while anxiogenic compounds reduce the value of these parameters [17]. In this study, A. ascalonicum at the dose of $100 \mathrm{mg} / \mathrm{kg}$ non-significantly increased the time spent in the open arms and significantly increased the number of entries into this compartment. As observed with diazepam, the extract at doses of 50 and $400 \mathrm{mg} / \mathrm{kg}$ significantly reduced the number of entries into the closed arms. The actions of $A$. ascalonicum in the elevated plus maze model in this study suggest anxiolytic property.

Barua et al. [8] reported the anxiolytic effect of a medicinal plant extract based on the increase in the number of rearing and assisted rearing, and number of squares traversed in the open field test. In this study, A. ascalonicum extract at the dose of $100 \mathrm{mg} / \mathrm{kg}$ increased the number of rearing and assisted rearing with effect being significant in respect of the former parameter. As observed with diazepam, the extract at doses of 50,100 , and $400 \mathrm{mg} / \mathrm{kg}$ significantly increased the number of sectional crossings with peak effect produced at the dose of $100 \mathrm{mg} / \mathrm{kg}$. This observation is consistent with the results obtained in the hole-board test. The results obtained in the open field test also suggest that $A$. ascalonicum possess anxiolytic activity with associated enhancement of locomotion.

According to Bourin and Hascoet [11], the light/dark test is based on the innate aversion of rodents to brightly illuminated areas and on the spontaneous exploratory behavior of rodents in response to mild stressors including novel environment and light. Accordingly, this test may be useful to predict anxiolytic-like or anxiogenic-like activity in mice. Transitions have been reported to be an index of activity-exploration because of habituation over time, and the time spent in each compartment to be a reflection of aversion [18]. In this study, A. ascalonicum (50$400 \mathrm{mg} / \mathrm{kg}$ ) significantly increased the latency of entry into the dark compartment and time spent in the light box. Diazepam also significantly increased the time spent in the light box and reduced the duration of stay in the dark section. The extract $(50-400 \mathrm{mg} / \mathrm{kg})$ also significantly increased the number of rearing and assisted rearing. Diazepam also increased the number of rearing and assisted rearing but the effect was only significant in respect of the later. The effects 
observed with $A$. ascalonicum in the light/dark exploration test suggest anxiolytic activity with peak action generally elicited at the dose of $100 \mathrm{mg} / \mathrm{kg}$.

In the social interaction test, the amount of time a pair of rodents spend socially interacting with one another is thought to reflect the level of anxiety and the duration of social interaction decreases with increased anxiety [12]. Anxiolytic activity, apart from being indicated by increase in the duration of social interaction (by way of sniffing, following, and grooming), may also be suggested by increase in the number of social interaction within a specified period of time relative to the negative control group. In this study, A. ascalonicum increased the number of social interactions with significant and peak effect produced at the dose of $100 \mathrm{mg} / \mathrm{kg}$. This result confirms the anxiolytic effect of the extract as indicated in the results obtained in the other established models used in this study.

The pharmacological actions of medicinal plants are due to the presence and manifestations of bioactive compound(s). It has been established that a lot of plant secondary metabolites are being employed in the treatment of psychotic disorders especially anxiety in traditional medicine practice, most of which directly or indirectly affect the CNS, noradrenaline, serotonin, GABA and benzodiazepine neurotransmitters activities [8, 19, 20]. Phytochemical screening of the aerial part hydroethanolic extract of $A$. ascalonicum in this study revealed the presence of alkaloids, tannins, glycosides, anthraquinones, phlobatannins, and flavonoids. Previous phytochemical analysis of shallot extracts has confirmed the presence of flavone, quercetins, ascalin and furostanol saponins $[13,21,22]$. The anxiolytic activity of $A$. ascalonicum identified in this study may be due to the presence of one or a combination of phytoconstituents present in the extract. Flavonoids, alkaloids, and terpenoids have been reported to be responsible for anxiolytic and sedative effects observed in different plant extracts [23-25]. According to Wasowski and Marder [26], some natural flavonoids have been shown to possess selective affinity for the benzodiazepine binding site with a broad spectrum of CNS effects and a list of successful synthetic derivatives has been generated with enhanced activities.

In respect of acute toxicity, the aerial part hydroethanolic extract of $A$. ascalonicum did not produce any mortality and visible signs of delayed toxicity administered p.o. up to $10 \mathrm{~g} / \mathrm{kg}$. Hayes [27] stated that no dose-related toxicity should be considered above $5 \mathrm{~g} / \mathrm{kg}$ body weight, thus suggesting that the extract is relatively non-toxic administered p.o. However, the $\mathrm{LD}_{50}$ when administered i.p. was estimated to be $2238.72 \mathrm{mg} / \mathrm{kg}$.

\section{CONCLUSION:}

The results obtained in this study suggest that the aerial part hydroethanolic extract of Allium ascalonicum possesses anxiolytic activity due to one or a combination of phytoconstituents identified in the extract. Further investigations are ongoing in our laboratory to isolate, identify and characterize the chemical principle(s) responsible for the observed biological property of the extract and the precise mechanism(s) of action.

Authors' disclosure statement: The authors declare that there are no conflicts of interest, financial or non-financial, in the design, conduct, and report of this study. 
Authors' contribution: AJA designed the study, analyzed and interpreted results and wrote up the manuscript; HAS and PCE performed the experiments and generated the results under the supervisor of AJA; and all authors read and approved the submission of the manuscript.

\section{REFERENCES:}

1. Wambebe C: Development of standardized phytomedicines in Africa. Journal of Pharmaceutical Research and Development 1998, 3: 1-11.

2. Gilani AH, Atta-ur-Rahman: Trends in ethnopharmacology. Journal of Ethnopharmacology 2005, 100(1-2): 43-49.

3. Fennell CW, Lindsey KL, McGaw LJ, Sparg SG, Stafford GI, Elgorashi EE, Grace OM, van Staden J: Assessing African medicinal plants for efficacy and safety: pharmacological screening and toxicology. Journal of Ethnopharmacology 2004, 94: 205-217.

4. Akindele AJ, Adeyemi OO: Anxiolytic and sedative effects of Byrsocarpus coccineus Schum. and Thonn. (Connaraceae) extract. International Journal of Applied Research in Natural Products 2010, 3(1): 28-36.

5. Committee for the Update of the Guide for the Care and Use of Laboratory Animals. Guide for the Care and Use of Laboratory Animals (Eighth Edition). National Academy of Sciences, National Academies Press, Washington DC, USA, 2011.

6. Randhawa MA: Calculation of $\mathrm{LD}_{50}$ values from the method of Miller and Tainter, 1944. Journal of Ayub Medical College Abbottabad 2009, 21(3): 184-185.

7. Trease GE, Evans WC: 1989. Pharmacognosy (13th edition). Brailliar Tiridel Can. Macmillian Publishers.

8. Barua CC, Roy JD, Buragohian B, Barua AG, Borah P, Lahkar M: Anxiolytic effect of hydroethanolic extract of Drymaria cordata L Willd. Indian Journal of Experimental Biology 2009, 47: 969-973.

9. Vogel HG, Vogel WH: Elevated plus maze test. In: Drug discovery and evaluation. SpringerVerlag Berlin Heidelberg, New York, 1997, pp 234.

10. Anisman H, Matheson K: Stress, depression, and anhedonia: caveats concerning animal models. Neuroscience and Biobehavioral Reviews 2005, 29: 525-546.

11. Bourin M, Hascoët M: The mouse light/dark box test. European Journal of Pharmacology 2003, 463(1-3): 55-65.

12. Wijeweera P, Arnason JT, Koszycki D, Merali Z: Evaluation of anxiolytic properties of Gotukola - (Centella asiatica) extracts and asiaticoside in rat behavioral models. Phytomedicine 2006, 13: 668-676.

13. Zarei Mahmoudabadi A, Gharib Nasery MK: Anti fungal activity of shallot, Allium ascalonicum Linn. (Liliaceae) in vitro. Journal of Medicinal Plants Research 2009, 3(5): 450-453.

14. Adeniyi BA, Anyiam FM: In vitro anti-Helicobacter pylori potential of methanol extract of Allium ascalonicum Linn. (Liliaceae) leaf: susceptibility and effect on urease activity. Phytotherapy Research 2004, 18: 358-361.

15. Takeda H, Tsuji M, Matsumiya T: Changes in head-dipping behavior in the hole-board test reflect the anxiogenic and/or anxiolytic state in mice. European Journal of Pharmacology 1998, 350(1): 21-29. 
16. Rang HP, Dale MM, Ritter JM, Moore PK: In: Pharmacology, $5^{\text {th }}$ edition. Churchill Livingstone, London, 2003, 515.

17. Ali A, Venkat Rao N, Shalam M, Shivaraj Gouda T, Babu JM, Shantakumar SM: Anxiolytic activity of seed extract of Caesalpinia bonducella (Roxb) in laboratory animals. The Internet Journal of Pharmacology 2008, 5(2): DOI: 10.5580/2438

18. Belzung C, Misslin R, Vogel E, Dodd RH, Chapouthier G: Anxiogenic effects of methyl- $\beta$ carboline-carboxylate in a light/dark choice situation. Pharmacology, Biochemistry and Behavior 1987, 28: 29-33.

19. Wolfman C, Viola H, Paladini A, Dajas F, Medina JH: Possible anxiolytic effects of chrysin, a central benzodiazepine receptor ligand isolated from Passiflora coerulea. Pharmacology, Biochemistry and Behavior 1994, 47: 1-4.

20. Dhawan K, Dhawan S, Chhabra S: Attenuation of benzodiazepine dependence in mice by a trisubstituted benzoflavone moiety of Passiflora incarnate Linneaus: A non-habit forming anxiolytic. Journal of Pharmacy and Pharmaceutical Sciences 2003, 6: 215-222.

21. Wang HX, Ng TB: Ascalin, a new anti-fungal peptide with human immunodeficiency virus type 1 reverse transcriptase-inhibiting activity from shallot bulbs. Peptides 2002, 23: 1025-1029.

22. Fattorusso E, Iorizzi M, Lanzotti V, Taglialatela-Scafati O: Chemical composition of shallot (Allium ascalonicum Hort.). Journal of Agricultural and Food Chemistry 2002, 50: 5686-5690.

23. Houghton PJ: The scientific basis for the reputed activity of valerian. Journal of Pharmacy and Pharmacology 1999, 51: 505-512.

24. Dhawan K, Kumar S, Sharma A: Anti-anxiety studies on extracts of Passiflora incarnata Linneaus. Journal of Ethnopharmacology 2001, 78: 165-170.

25. Carlini EA: Plants and the central nervous system. Pharmacology, Biochemistry and Behavior 2003, 75: 501-512.

26. Wasowski C, Marder M: Flavonoids as $\mathrm{GABA}_{\mathrm{A}}$ receptor ligands: the whole story? Journal of Experimental Pharmacology 2012, 4: 9-24.

27. Hayes AW: Guidelines for acute oral toxicity testings. In: Principles and Methods of Toxicity, second ed. Raven Press Ltd., New York, Table 4, 1989, pp. 185. 